\title{
The Influence of Information Technology Toward Interest in Utilization of The Virtual Learning Environment
}

\author{
Wildoms Sahusilawane, Lilian Sarah Hiariey \\ Universitas Terbuka, Ambon Regional Office, Indonesia
}

\begin{tabular}{|c|c|}
\hline Article Info & ABSTRACT \\
\hline Article history: & \multirow{10}{*}{$\begin{array}{l}\text { This research aims at examining the effect of Ease, Affect, Flexibility and } \\
\text { Accessibility of information technology on utilizing virtual learning } \\
\text { environment at Universitas Terbuka. The population of the research consists } \\
\text { students of Bidikmisi scholarship in Non Basic Education program of } \\
\text { Accounting that include of } 145 \text { respondents. The sampling method is } \\
\text { purposive sampling with } 141 \text { eligible samples. The questionnaires are } \\
\text { measured with Correlation and Multiple Regression analysis that covers } \\
\text { descriptive statistics, reliability test and validity test. Classical Assumption } \\
\text { Test which includes multcollinearity test is later conducted. Hypothesis } \\
\text { testing and discussion are presented at the end. Result of research with t test } \\
\text { or partially indicate that, variable of ease of use have positive relation and } \\
\text { have significant influence to interest of utilization of virtual learning } \\
\text { environment, t test result for accessibility variable have positive relation and } \\
\text { no significant effect to interest of utilization of virtual learning environment. } \\
\text { The result of the research on the affect variable has a positive relationship } \\
\text { and has a significant effect on the interest of utilizing the virtual learning } \\
\text { environment. While the flexibility variable shows have a negative } \\
\text { relationship and no significant effect on the interest of utilization of virtual } \\
\text { learning environment. }\end{array}$} \\
\hline Received Jan 25, 2018 & \\
\hline Revised May 9, 2018 & \\
\hline Accepted May 23, 2018 & \\
\hline Keywords: & \\
\hline Accessibility & \\
\hline Affect & \\
\hline Ease & \\
\hline Flexibility & \\
\hline Interest in utilization & \\
\hline
\end{tabular}

Copyright $\odot 2018$ Institute of Advanced Engineering and Science. All rights reserved.

\section{Corresponding Author:}

Wildoms Sahusilawane,

Universitas Terbuka, Ambon Regional Office,

Jl. Wolter Monginsidi, Ambon, Indonesia.

Email: wildoms@ecampus.ut.ac.id

\section{INTRODUCTION}

Distance learning system at Universitas Terbuka is completely different from face-to-face learning system. Students at Universitas Terbuka are obliged to be able to learn independently by using the provided facilities and exposing the students' full potentials to achieve the desirable goals. As a distance-education platform, one of the prominent characterictics of Universitas Terbuka refers to an educational process between students and teachers separated by physical distance. The distance is overcome by relying on information technology as a learning and communication platform that helps support the distance education.

The role of information technology in every aspect of education, both formal and non formal, counts on managing and processing information system via computing technology in its various forms. Information technology provides any information required by education system fast, aptly, relevantly and acurately. It generates faster work as well as relevant and accurate outputs in respect of data processing in organizational activities [1]. The interest in using technology is highly related to the users' attitudes. By their very nature, individuals are interested in operating technology to their liking. According to Aaker and Myers [2], individuals' attitude toward a certain product clearly shows their like or dislike of the product.

A research by Sagung [3] analyzes factors that affect the use of information technology in Bank Perkreditan Rakyat in Tabanan Regency. He finds that social factor and facilities positively and significantly effect the use of information technology. Affect, task conformity and long-term consequence have positive 
and insignificant impact, while complexity has negative and insignificant impact on the use of information technology.

Furthermore, the rapid increase of information technology users improves the benefit value of the virtual learning environment itself. This therefore enables students to acquire as much information related to majors they are in through facilities that include digital contents accessible and exchangeable anywhere and anytime. Zeithahml [4] defines the factors that measure the quality of online service, which are accessibility, ease of navigation, efficiency, site aesthetics and personalization.

Based on the above explanation, Universitas Terbuka as one of the universities that implement the distance learning system is the utilization of information technology in this case the internet to do the learning process. From the condition that there are still many students who have not utilized the internet as a learning environment due to lack of existing infrastructure, so that students can not access the internet maximally.

According to O'Brien [5], technology is a computer network that consists of numerous components of information processing which applies myriad hardwares, softwares, data management and network information technology.

According to Antasari and Yaniartha [6] system information can be a success if the system can run with good, easy to implement, and in accordance with existing technology. One will be interested in using a new information technology when the users are convinced by using the information technology will improve its performance, using information technology to do with ease, and the user is getting the environmental effects surrounding the use of information technology [7].

According to Handayani [8], an organization applies technology to provide information for both internal and external users in decision-making. Technology that generates information is defined as information technology, which is a combination between computing technology and telecommunication which involves such other technology as hardwares, softwares, databases, network technolgy, etc.

Online service in education, degree or non degree, is generally to provide education service for users (students, in this sense) by using the Internet as the ultimate platform. The online service consists of various phases, which include registration, entrance test, payment, assignments, discussions, examinations, assessments, announcement, and so on. Distance education could make use of the Internet optimally, which in turn provides the students control of time and place and even optimizes the quality of education.

Online distance education overcomes the limit that any other types of distance education suffer (which have actually been technologically-based education). The limit refers to such technologies as satellites and televisions. With both technologies, students still have to attend the education facilities with special and costly equipments. Online education via the Internet, on the other hand, enables the students to study independently at home by using their own computers.

According Jogiyanto [9], Interest in the utilization of information systems is a desire (interest) someone to perform a particular behavior by utilizing information systems. One will be interested in using a new information technology if the user believes by using information technology will improve its performance, using information technology can be done easily, and the user gets the influence of the surrounding environment in using the information technology [7].

Virtual learning refers to a Web-based learning process by including Cyberspace and Internet [10]. It aims at removing the barrier of space and time between students and teachers via computers. Students are able to obtain learning materials designed in learning packages availabe in the Internet.

Accessibility refers to the easiness to reach a certain purpose that can provide comfort in performing a certain activity [11]. To enable the students to look up information fast, aptly and accurately, information technology and communication are available to create greater access to such information and communication. Furthermore, the ever-increasing Internet, which has covered rural areas, makes it all the easier for them to look up extensive range of information spread all over the world without traveling.

Affect is defined as personal feeling or emotion, either pleasant or unpleasant. Agus [12] proves that an individual's feeling has positive and significant impact on the use of information technology. In other words, if an individual feels content doing his/her work by using information technology, he/she tends to improve the use of it.

The flexibility of an information system indicates that the information system is considered successful if the system users can meet their needs flexibly and away from the difficulty and comfortable in using the system [13]. Based on the aforesaid description, this research aims at examining the effect of Ease, Affect, Flexibility and Accessibility of the use of information technology on the interest in using virtual learning environment. The objective of the research is to empirically examine such factors as Ease, Affect, Flexibility and Accessibility of the use of information technology on the interest in the development of virtual learning environment at Universitas Terbuka. 


\section{RESEARCH METHOD}

The sampling method applied in this research is purposive sampling, which is selected based on the characteristics of a population, data source and the purpose of the research. Data sources encompass primary data directly obtained from the field. The data testing technique is Correlation and Multiple Regression analysis. The analysis result is presented in descriptive statistics, data quality test, classical assumption test, regression analysis and hypothesis test to find out the interrelationship between independent variables and dependent variables.

\section{RESULTS AND ANALYSIS}

Primary data in this research is collected by delivering 150 questionnaires to respondents who take advantage of the virtual learning environment. Those respondents are students at 6 UPBJJ, among which are Ambon, Denpasar, Ternate, Palembang, Gorontalo and Surakarta. Those questionnaires are directly delivered to them by UPBJJ staff.

The number of questionnaires returned is 145 exemplars or $96,6 \%$ of the total distributed questionnaires, which is 150 questionnaires. The number of which that can be processed is 141 exemplars or $94 \%$, where the remaining 4 are not eligible due to incomplete answers and damage. The researcher classifies those respondents based on sex, age, the type of virtual service that they use, the duration and the location of accessing the Internet. The complete data can be seen in Table 1.

The number of respondents eligible for the data processing in this research is 141 people. The overview of the respondents' profiles are shown in Table 1.

Table 1. The Profile of Respondents

\begin{tabular}{lcc}
\hline \multicolumn{1}{c}{ Description } & Total & Percentage (\%) \\
\hline Sex: & 38 & $26,95 \%$ \\
a. Male & 103 & $73,05 \%$ \\
b. Female & & \\
Age: & 128 & $90,78 \%$ \\
a. 17 - 21 years old & 13 & $9,22 \%$ \\
b. 22 - 30 years old & & \\
The Use of Virtual Learning Environment & 48 & $34,04 \%$ \\
a. Tutorial Online & 8 & $5,67 \%$ \\
b. Digital Library & 0 & 0 \\
c. Dry Lab & 65 & $46,10 \%$ \\
d. Independent Exercises & 20 & $14,18 \%$ \\
e. Others & & \\
Places of accessing the Internet & 13 & $9,22 \%$ \\
a. Campus & 70 & $49,65 \%$ \\
b. Internet cafe & 50 & $35,45 \%$ \\
c. House & 8 & $5,67 \%$ \\
d. Hotspot & & \\
\hline
\end{tabular}

Table 1 displays that out of 141 respondents, females outnumber males, where there are 103 females $(73,05 \%)$ and 38 males $(26,95 \%)$. Meanwhile, based on age, there are 128 respondents aged 17-21 years old while there are 13 students aged 22-30 years old.

Based on the use of virtual learning environment, the table shows that the most attended service by students is Latihan Mandiri with 65 students $(46,10 \%)$. The second most attended service is tutorial online with 48 students $(34,04 \%)$. Students who attend other services are 20 students $(14,18 \%)$, while the least attended is digital library with only 8 students $(5,67 \%)$.

Based on the places at which they access the Internet to make use of the virtual learning environment, Internet cafe is the most visited with 70 students $(49,65)$, followed by house with 50 students $(35,46 \%)$. Campus and hotspot comprise 13 students $(9,22 \%)$ and 8 students $(5,67 \%)$ respectively.

Based on the aforesaid analysis method, the first test conducted in this research is data quality test. Data quality test includes validity test and reliability test.

A variable is declared reliable, if Results $\alpha>0.6=$ Reliable, Results $\alpha<0.6=$ unreliable [14]. Validity indicates the extent to which the measuring instrument capable of measuring what is measured [15]. 


\begin{tabular}{|c|c|c|}
\hline No & Variabel & Cronbach's Alpha \\
\hline 1 & Ease & 0,683 \\
\hline 2 & Affect & 0,746 \\
\hline 3 & Accessibility & 0,618 \\
\hline 4 & Flexibility & 0,778 \\
\hline 5 & Interest in utilizing the virtual learning environment & 0,678 \\
\hline
\end{tabular}

As shown in Table 3, the Cronbach's alpha for the overall scale is equal to 0.700. All the measures employed in this study demonstrated good internal consistency, ranging from 0.618 to 0.778 . A test of validity showed that the correlation coefficients between each statement and the total score were between 0.523 and 0.848 , all of them being significant at $p<0.05$. It is It can be concluded that every question for the variables in this research is valid.

Multiple linear regression attempts to detect the relationship between an independent variable and a dependent variable. The relationship between independent variable and dependent variable are to be simultaneously calculated in multiple regression equation.

Table 3. Multiple Linear Regression Test

\begin{tabular}{llcc}
\hline \multirow{2}{*}{ Model } & \multicolumn{2}{c}{ Unstandardized Coefficients } \\
\cline { 2 - 4 } \cline { 2 - 3 } & (Constant) & B & Std. Error \\
\hline KTI & .483 & 1.580 \\
& ACC & .409 & .092 \\
& AFF & .061 & .095 \\
& FLK & .342 & .053 \\
\hline
\end{tabular}

Based on the table, the regression equation is as follows:

$$
Y=4,483+0,409 X_{1}+0,061 X_{2}+0,342 X_{3}-0,060 X_{4}
$$

Based on the regression equation, the constant $(\beta 0)$ is $(\beta 0) 4,483$ which indicates that there is no sign of change in variables of Ease $\left(X_{1}\right)$, Accessibility $\left(X_{2}\right)$, Affect $\left(X_{3}\right)$ and Flexibility $\left(X_{4}\right)$. This accordingly means that the interest in utilizing the virtual learning environment is 4,483 .

Coefficient of determination $\left(R^{2}\right)$ is principally a measure used to assess how well a model explains the dependent variable. The coefficient of determination ranges from 0 to 1 . Lower $R^{2}$ means less capability of the independent variables to explain the dependent variable. A value close to one independent variable provide almost all the information needed to predict the dependent variable [14]. The result of the coefficient of determination test is presented in the following Table 4:

Table 4. Coefficient of Determination

\begin{tabular}{lcccc}
\hline Model & R & R Square & Adjusted R Square & Std. Error of the Estimate \\
\hline 1 & $.690^{\mathrm{a}}$ & .477 & .461 & 1.383 \\
a. Predictors: (Constant), FLK, KTI, AFF, ACC & \\
b. Dependent Variable: MTI & \\
\hline
\end{tabular}

Table 4 , model summary, reveals that the adjusted $R^{2}$ is 0,461 or $46,1 \%$. This indicates that each of the independent variables-Ease, Accessibility, Affect and Flexibility-is able to explain the dependent variable-Interest in utilizing the virtual learning environment-which is $46,1 \%$. As for the remaining $53,9 \%$, it is explained by other factors or variables unknown and excluded in the regression analysis.

F Test is a measure used to find out the simultaneous effect of independent variables (free variables) on dependent variables (bound variables). The following Table 5 represents the result of simultaneous significance test (Statistic-F Test): 
Table 5. Result of F Test

\begin{tabular}{|c|c|c|c|c|c|c|}
\hline \multicolumn{7}{|c|}{ ANOVA $^{\mathrm{b}}$} \\
\hline \multicolumn{2}{|c|}{ Model } & Sum of Squares & Df & Mean Square & $\mathrm{F}$ & Sig. \\
\hline \multirow[t]{3}{*}{1} & Regression & 237.035 & 4 & 59.259 & 30.982 & $.000^{\mathrm{a}}$ \\
\hline & Residual & 260.128 & 136 & 1.913 & & \\
\hline & Total & 497.163 & 140 & & & \\
\hline \multicolumn{7}{|c|}{ a. Predictors: (Constant), FLK, KTI, AFF, ACC } \\
\hline \multicolumn{7}{|c|}{ b. Dependent Variable: MTI } \\
\hline
\end{tabular}

Table 5 reveals that $\mathrm{F}$ calculate is 30,982 with 0,000 siginificance level. Since 0,000 significance is much lower than 0,05 , it can be concluded that Ho is rejected. That means there is a simultaneous effect of Ease, Affect, Accessibility and Flexibilitty on Interest in utilizing virtual learning enviroment.

Statistic-T test is a measure to discover the effect of one independent variable, one at a time, in explaining the variance of dependent variable. The result of the partial test (T-test) is shown in the following Table 6:

Table 6. Result of Statistic-T Test

\begin{tabular}{|c|c|c|c|c|c|c|}
\hline & & \multicolumn{2}{|c|}{ Unstandardized Coefficients } & \multirow{2}{*}{$\begin{array}{c}\text { Standardized Coefficients } \\
\text { Beta }\end{array}$} & \multirow[t]{2}{*}{$\mathrm{T}$} & \multirow[t]{2}{*}{ Sig. } \\
\hline \multicolumn{2}{|c|}{ Model } & B & Std. Error & & & \\
\hline 1 & (Constant) & 4.483 & 1.580 & & 2.837 & .005 \\
\hline & KTI & .409 & .092 & .329 & 4.459 & .000 \\
\hline & $\mathrm{ACC}$ & .061 & .095 & .046 & .642 & .522 \\
\hline & $\mathrm{AFF}$ & .342 & .053 & .452 & 6.430 & .000 \\
\hline & FLK & -.060 & .069 & -.054 & -.867 & .387 \\
\hline
\end{tabular}

The result of T-test on variable Ease shows that the level of significance stands at 0,000 , which is below 0,05 . That indicates that Ho is accepted which means the easy operation of information technology has a partially significant impact on the use of virtual learning environment.

The result of T-test on variable Accessibility reveals that the level of significance stands at 0,522 , higher than 0,05, which leads Ho to be accepted. That means variable Accessibility partially does not have significant impact on the interest in utilizing the virtual learning environment.

The T-test on variable Affect generates 0,000 significance level, which is less than 0,05. Ho is therefore rejected which leads to the fact that partially Affect has a significant impact on the interest in utilizing the virtual learning environment.

As for variable Flexibility, the T-test reveals that the level of significance stands at 0,387, which is greater than 0,05. Hence, Ho is accepted, which leads to the conclusion that Flexibility partially has an insignificant impact on the interest in utilizing the virtual learning environment.

\subsection{Discussion}

The finding of the research reveals that the easily-operated information technology has provided positive and significant effect on the interest in utilizing virtual learning environment. The easier the operation of the information technology in the virtual learning environment, the easier for students as users to access online services provided by Universitas Terbuka to conduct virtual learning process.

The use of information technology is increasingly high in the learning process requires ease of access to services available so the higher the ease of using the system, the higher the level of utilization of information technology in the learning process. The results of this study also support the results of research conducted by Elistya Rimawati and Sri Harjanto [16] which states that the ease of significant and positive influence on the dependent variable interest of junior high school teachers use the Internet as a source of learning partially. This research is also in line with the research conducted by Fitri Imandari [17] there was significant influence between the perception of the ease of use of behave in interest towards e-learning.

The research points out that accessibility does not significantly affect the interest in utilizing virtual learning environment. This proves that the accessibility to the digital resources available at Universitas Terbuka has yet to be fully utilized due to the fact that most students are more likely to access the Internet in such other places as the Internet cafe at their own expenses. It is recommended that the hotspot access be 
extended to UPBJJ-UT campus or office surrounding areas. The technology's integration enables them to easily access any virtual services at UT necessary to sustain their education.

The research sets out that affect has positive and significant effect on the interest in using virtual learning environment. Students who are profoundly content and keen on studying with technology services are to expand the use of the virtual learning environment, which in turn allows them to improve their academic achievement. This is in line with a research by Wulandari [18] which claims that affect, showing to its positive and insignificant impact, has been closely associated in utilizing information technology.

The research proposes that flexibility does not significantly affect the interest in utilizing virtual learning environment. For the most part, technology infuses learning environment with digital learning tools that enable online learning opportunities and increase educational productivity. However, merely having some sort of technological devices is an outdated standars. Keeping up with the technology does not necessarily means keeping up with the students' needs. That means most students feel discontented with the fact that the information technology system available at Universitas Terbuka is not yet flexible when it comes to adapting the students' needs.

That flexibility of the use of internet-based learning media can support efforts to expand access and learning services for students wherever located. The results of this study do not support the research conducted by Sidiq, Zulkilfi [19] which states that $54.35 \%$ of the SDLB teachers view the information technology-based learning media give a good influence in making the learning process becomes more flexible.

\section{CONCLUSION}

The research verifies the effect of easy use, accessibility, affect and flexibility on the interest in utilizing the virtual learning environment. The conclusion is as follows:

a. Variable of ease of information technology as to the interest in utilizing the virtual learning environment is empirically proven with T-test as significant.

b. Variable of accessibility is empirically proven with T-test as insignificant for the interest in utilizing the virtual learning environment owing to the limited Internet access that leads the respondents to inevitably fall behind the virtual learning environment.

c. Variable of affect is empirically proven with T-test as significant for the interest in utilizing the virtual learning environment. This denotes that the respondents feel tremendously content and determined to get engaged in the online learning process.

d. Variable of flexibility is empirically proven with T-test as insignificant for the interest in utilizing the virtual learning environment, which does not meet the respondents' needs and expectations with respect to the digital learning services.

The research raises a number of future opportunities and is open to scrutiny and challenge. The aforementioned findings are expected to be taken into a deep consideration as regards the management of distance-education in order to improve the virtual learning process that heavily relies on information technology system.

a. This research provides indications and contributions regarding a number of notable issues in utilizing information technology that Universitas Terbuka is dealing with in order to carry out as well as to improve the desirable and necessary virtual-learning environment.

b. This research sets a number of opportunities for forthcoming researches in PTJJ, both in terms of theory development and concept validation, which especially concern with the development of information technology in learning process.

\section{REFERENCES}

[1] Wilkinson, J.W and Cerullo M.S. "Accounting Information System": Essential Concept and Aplication. Edisi 3 John Willey and Sons, New York. 1997.

[2] Aakers, David, A dan Myers, John, G. Advertising Management (New Jersey Prentce Hall inc) 1997.

[3] Sagung Rai Darmini. 2008. "Analisis Faktor-Faktor yang Mempengaruhi Pemanfaatan Teknologi Informasi dan Pengaruh Pemanfaatan dan Kepercayaan terhadap Teknologi Informasi pada Kinerja Individual pada Bank Perkreditan Rakyat di Kabupaten Tabanan". Skripsi Fakultas Ekonomi Universitas Udayana Denpasar.

[4] V. Zeithaml, A. Parasuraman and A. Malholtra, A Conceptual Framework to Understanding E-Service Quality: Implication For Future Research and Managerial Practice. Marketing Science Instutition Report No. 00-115. 2000

[5] O’Brien, James A. Pengantar Teknologi Sistem Informasi Perspektif Bisnis dan Manajerial. Jakarta: Salemba Empat. 2006. 
[6] Antasari, K. C., \& Yaniartha, P. D. 2015. Pengaruh Efektivitas Sistem Informasi Akuntansi Dan Penggunaan Teknologi Informasi Pada Kinerja Individual Dengan Kepuasan Kerja Sebagai Variabel Pemoderasi. E-Jurnal Akuntansi Universitas Udayana 10.2, 354-369.

[7] Jati, N.J. 2012. "Analisis Faktor-Faktor Yang Mempengaruhi Minat Pemanfaatan Dan Penggunaan Sistem E-Ticket (Studi Empiris Pada Biro Perjalanan Di Kota Semarang)". Skripsi Fakultas Ekonomika dan Bisnis Universitas Diponegoro.

[8] Handayani, R. Analisis Faktor-Faktor yang mempengaruhi Minat Pemanfaatan Sistem Informasi dan Pengguna Sistem Informasi. Simposium Nasional Akuntansi X. Unhas Makassar, Juli 2007.

[9] Jogiyanto. Sistem Teknologi Keperilakuan. Yogyakarta: Andi. 2007.

[10] Pannen, P. Pengertian Sistem Pendidikan Terbuka dan Jarak Jauh. Dalam Tian Belawati, dkk. (Ed.), Pendidikan Terbuka dan Jarak Jauh. Jakarta: Universitas Terbuka. 1999. Hal. 11-29.

[11] Widyonarso, Eko Setyo. Tingkat aksesibilitas fasilitas sosial berdasarkan konsep unit lingkungan di perumnas banyumanik Semarang. Jurnal ruang, 2014, vol. 2(4)

[12] Agus Swidarmayana, I Kadek 2006. Analisis Faktor-faktor yang Berpengaruh terhadap Penggunaan Teknologi Sistem Informasi terhadap Kinerja Chief Accounting pada Perusahaan Cargo di Denpasar”. Skripsi Fakultas Ekonomi Universitas Udayana Denpasar.

[13] Yovita Widyadinata Dan Agus Arianto Toly. Pengaruh Kualitas Sistem, Kualitas Informasi, Ketepatan Waktu, Dan Kerahasiaan Terhadap Kepuasan Wajib Pajak Pengguna E-Filing. Tax \& Accounting Review, 2014, Vol. 4, No.1.

[14] Ghozali, Imam. "Aplikasi Analisis Multivariat dengan Program IBM SPSS 21, Update PLS Regresi". Semarang: Badan Penerbit Universitas Diponegoro. 2013.

[15] Siregar, Syofian. "Statistik Parametrik untuk Penelitian Kuantitatif”. Jakarta: Bumi Aksara 2013.

[16] Elistya Rimawati, pengaruh Persepsi Guru SMP Terhadap Minat Memanfaatkan Internet Sebagai Sumber Belajar, Jurnal Ilmiah Sinus, 2017, Vol. 15, No. 1.

[17] Imandari Fitri. Pengaruh Persepsi Kemanfaatan Dan Persepsi Kemudahan Terhadap Minat Berperilaku Dalam Penggunaan E-Learning (Studi Pada Dosen Fakultas Ilmu Administrasi Universitas Brawijaya), Jurnal Administrasi Bisnis, 2013, Vol. 3 No. 2.

[18] Wulandari. S.W, Sudarno. Analisis Faktor-Faktor yang Mempengaruhi Pemanfaatan Teknologi Informasi pada Akuntan Publik di Semarang. Diponegoro Journal of Accounting. 2013 Vol. 2. No. 1.

[19] Sidiq, Zulkilfi, Persepsi Guru SDLB terhadap Media Pembelajaran Berbasis Teknologi Informasi Dalam Mendukung Pembelajaran Anak Berkebutuhan Khusus Di Kecamatan Majalaya Kabupaten Bandung, Edutech. 2015, Vol 1 No 12. 